\title{
Site of Jesus Baptism: From Discovery to World List Heritage
}

\author{
Mohammad Waheeb \\ Queen Rania College of Heritage \& Tourism, Hashemite University, Amman, Jordan \\ Email address: \\ mwaheeb@hu.edu.jo

\section{To cite this article:} \\ Mohammad Waheeb. Site of Jesus Baptism: From Discovery to World List Heritage. International Journal of Archaeology. \\ Vol. 7, No. 1, 2019, pp. 1-7. doi: 10.11648/j.ija.20190701.11
}

Received: January 28, 2019; Accepted: March 30, 2019; Published: May 15, 2019

\begin{abstract}
The Baptism Site "Bethany beyond the Jordan" (Al-Maghtas) is located in the Jordan RiftValley, north of the Dead Sea between two major sites Jerusalem to the west, and Mount Nebo to the east. The site was discovered during 1996, excavations revealed the presenceof threedistinct archaeological areas on the eastern bank of Jordan River, first,Tell al-Kharrar, also known as Jabal Mar Elias (Elijahs Hill) second, the area of the Monastery with its Large Pool, and third,Churches of St. John the Baptist. "Bethany beyond the Jordan" is of immense religious significance to the majority of denominations of Christian faith all over the world, who have accepted this site with its architectural remains and arts as the location where Jesus of Nazareth was baptized by John the Baptist. This reference encouraged generations of monks, hermits, pilgrims, priests and believers to reside in and visit the site, and to leave behind testimonies of their devotion and religious activities, dating to between the 1 st and the 18th century AD.At present, the site has regained a popular status as pilgrimage destination for Christians, who continue to engage in baptism rituals on site. The site has gained the recognition of various churches around the world as World List Heritage Site by UNESCO in 2015 and considered as the actual site where early believers formed the early community of Christianity. The recovered architectural remains such as churches,mosaic floors,caves, andwater system,represent a majorcomplex built during Byzantine Period to commemorate sacred events for early believes.Since the excavations completed during 2002,the site has been extensively developed by the joint ofJordan Ministry of Tourism and Department ofAntiquities, but sensitively so - visitor numbers are controlled and the Visitors' Centre has been located at some distance from the site in an effort to preserve its sanctity. Other facilities include a restaurant, parking, and new churches werebuilt in the Baptism Sitefor praying.
\end{abstract}

Keywords: Archaeology, Baptism, Religion, Cultural Heritage, Roman \& Byzantine Age

\section{Introduction}

Bethany, beyond the Jordan, where John was baptizing," according to (John 1:28, while John 10:40) mentions an incident when Jesus escaped from hostile Jews in Jerusalem and "went away again across the Jordan to the place where John at first baptized".

The settlement where John the Baptist lived and baptized includes the hill where the Prophet Elijah is said to have ascended to heaven on a chariot of fire, according to Christian beliefs.

The site also includes a large number of historic churches, baptismal pools and caves that were inhabited by priests.

Situated on the eastern bank of the River Jordan, 8 kilometers north of the Dead Sea, the archaeological site consists of three distinct areas: Tell Al-Kharrar, also known as Jabal Mar-Elias (Elijah's Hill), the area of the churches of Saint John the Baptist near the river while the third site situated in the middle designedwith rooms functioned for accommodation, food, prayingand provided withwater installations. Situated in a pristine natural environment the site is believed to be the location where Jesus of Nazareth was baptized by John the Baptist. It features Roman and Byzantine remains including churches and chapels, a monastery, caves that have been used by hermits and pools in which baptisms were celebrated, testifying to the religious character of the place. The site is a Christian place of pilgrimage dated from $1^{\text {st }}-6^{\text {th }} \mathrm{AD}$. $^{* 1}$

\footnotetext{
* The Author supervised the field work of survey \& excavations in the Baptism Sitefrom 1996-2002, and documentation from 2003-till nowadays. The Site was added to UNESCO's World Heritage List, to become the fifth site in the Kingdom included in the list after Petra, QuseirAmra, Um Al Rassas and Wadi Rum. The decision was taken in 2015 during a World Heritage Committee Meeting in Bonn, Germany.
} 


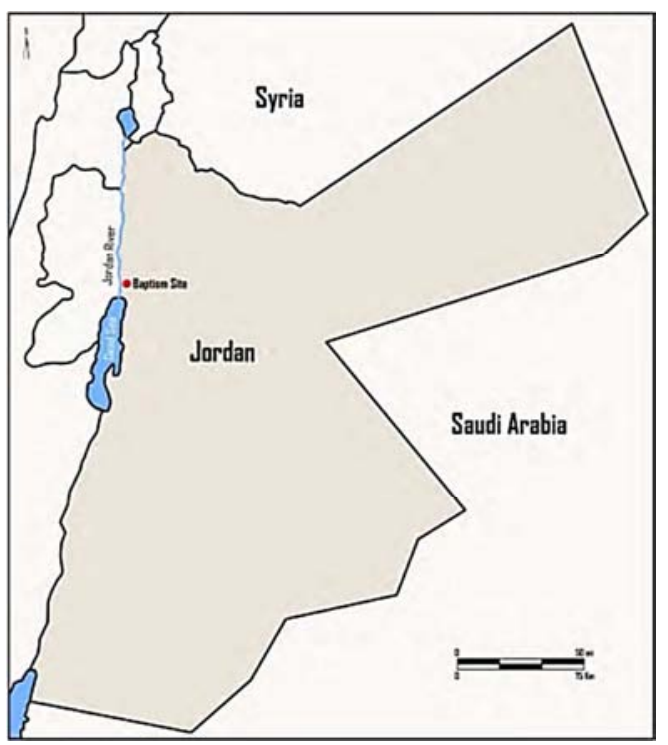

Figure 1. Location map of the Baptism Site /Bethany Beyond the Jordan.

\section{Site Significance}

The Jesus Baptism site has been an issue of core interest during the past few years and its location raised many questions. Finally archaeologists found the site located on its eastern bank of Jordan River. Obviously, the main factor that helped raise this old and yet new importance is the excavations carried out by a Jordanian team in Al Kahrar
Valley on the eastern side of the river. At least eight archeological sites were discovered during the excavations and most of them were monasteries, churches, caves, wells, pools, water installationin addition to ceramic pipes that were used to transfer water from the nearbyGharabah Valley, onekilometers to the south-east of Al Kharar valley. (Waheeb: 1997) [1] Figure 1. The variant-dimensional churches which were found with their floors covered with colorful mosaics. All of these discoveries show the importance of this site for faithful Christians. [2]

Why is it important? And why all these installations? To say that the location was used by pilgrims to rest as they were on their way to mount Nebo- the place where prophet Moses was buried in - is an insufficient answer because there must be other factors that attracted monks and hermits to settle in Al Kharrar valley. [3]

To identify these factors, the holy books must be thoroughly read and anything written by pilgrims and travelers describing the location as they visited it should also be analyzed.

First of all, the four Gospels agree that John the Baptist who was "a young leader" lived in the wilderness across Jordan, preaching at the baptism site to forgive sins. (Mark 1:4-5, Matthew 3:1, Luke 3:3, John 1:28, 3:26, 10:40).

He used to lead an ascetic life, wearing clothes from the hair of camels and taking shelter in caves to pave the way for the concepts of Jesus Christ and his teachings and lifting souls to spirituality.

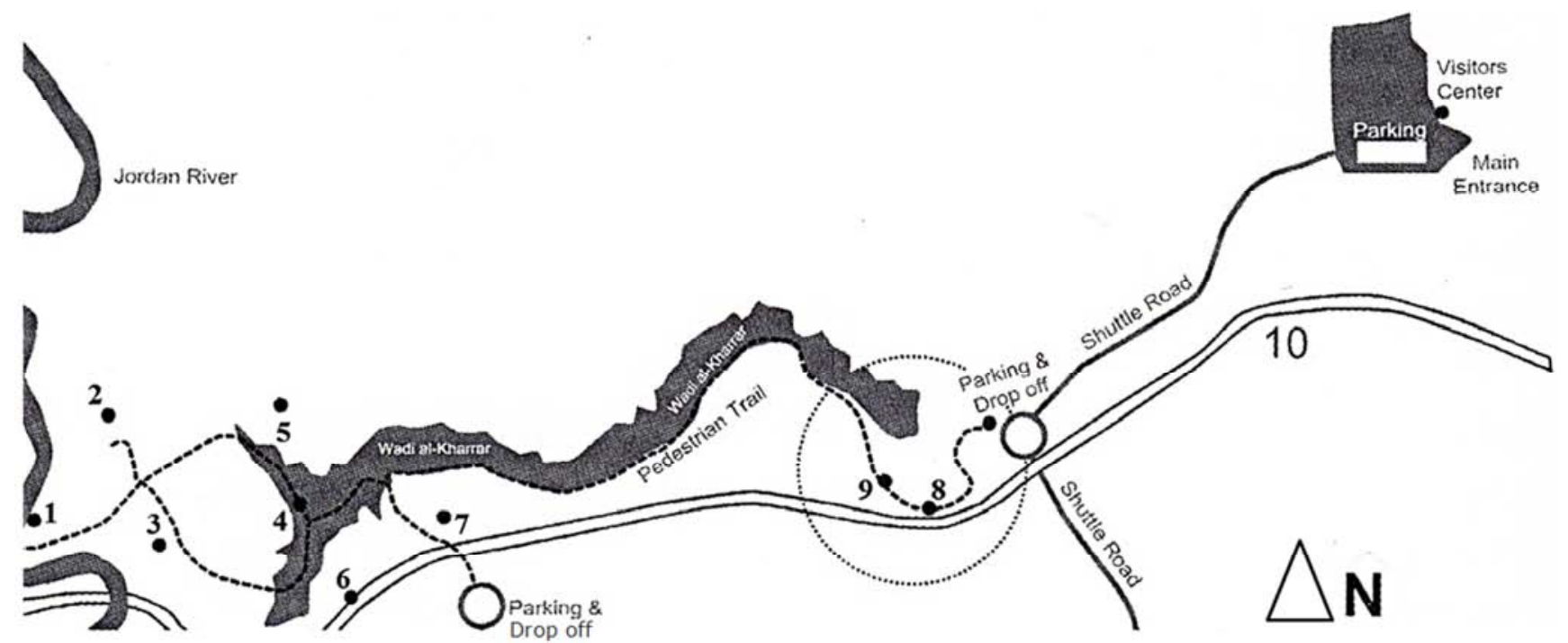

Figure 2. A map showing the location of the major archaeologicalsites found during excavations 1996-2002, no 1: Jordan River no 2-5 Churches and caves, no 6-7 Pilgrims station, no 8-9 Elijah's hill, no 10 old route [4].

If the four Gospels agree that John the Baptist lived in the wilderness in Jordan, John's bible was more specific and said that he lived in Bethany in Jordan, where John used to Baptize. One should note that there is another Bethany, three kilometers to the east of Jerusalem. It is known now as $\mathrm{Al}$ Eizariyeh in reference to Azar who was resurrected upon a miracle by Jesus Christ (John: 11,38). Figure 2.

Some scholars refer the name Bethany which is made of two parts to a man called Ananiya and other scholars believe that Bethany means the house of a boat. The most sound explanation is said that the name Bethany is taken from the Aramaic word "Bethanwaya" which means the house of a hermit, i.e. a monastery [5].The caves in Al Kharrar valley became the best place for hermits who established monasteries to perform their prayers and meditation [6]. The place was also known as "Bethabara" i.e., the House of the Crossing which is the place that was used by believers to cross into the other side of Jordan River. The first person to 
call this place Bethabara was Origen who came into the Holy Lands in the middle of the third century to visit Holy sites that was linked with Jesus Christ as well as other prophets. Origen found it odd naming the location at Al Karrar Valley as Bethany, saying that Bethany is a village for Azar, Martha and her sister Mary. He said it is located 25 kilometers from Jerusalem, adding that there is no place known as Bethany is Jordan; however there is Bethabara in the hilly areas in Jordan, where John the Baptist used to baptize. [7]
The same name was used by Eusibuos Cesarean, referred to Cesarean in Palestine. In the year $320 \mathrm{AD}$, Qaysari composed a dictionary known as "The Dictionary of Torah Sites". He reiterated that Bethabara is located across Jordan where John the Baptist used to Baptize. He added that the place is well-known for believers who wish to be brought to life again by being baptized there in lively water. This means that the rituals of baptism used to take place in Bethabara across Jordan. [8]

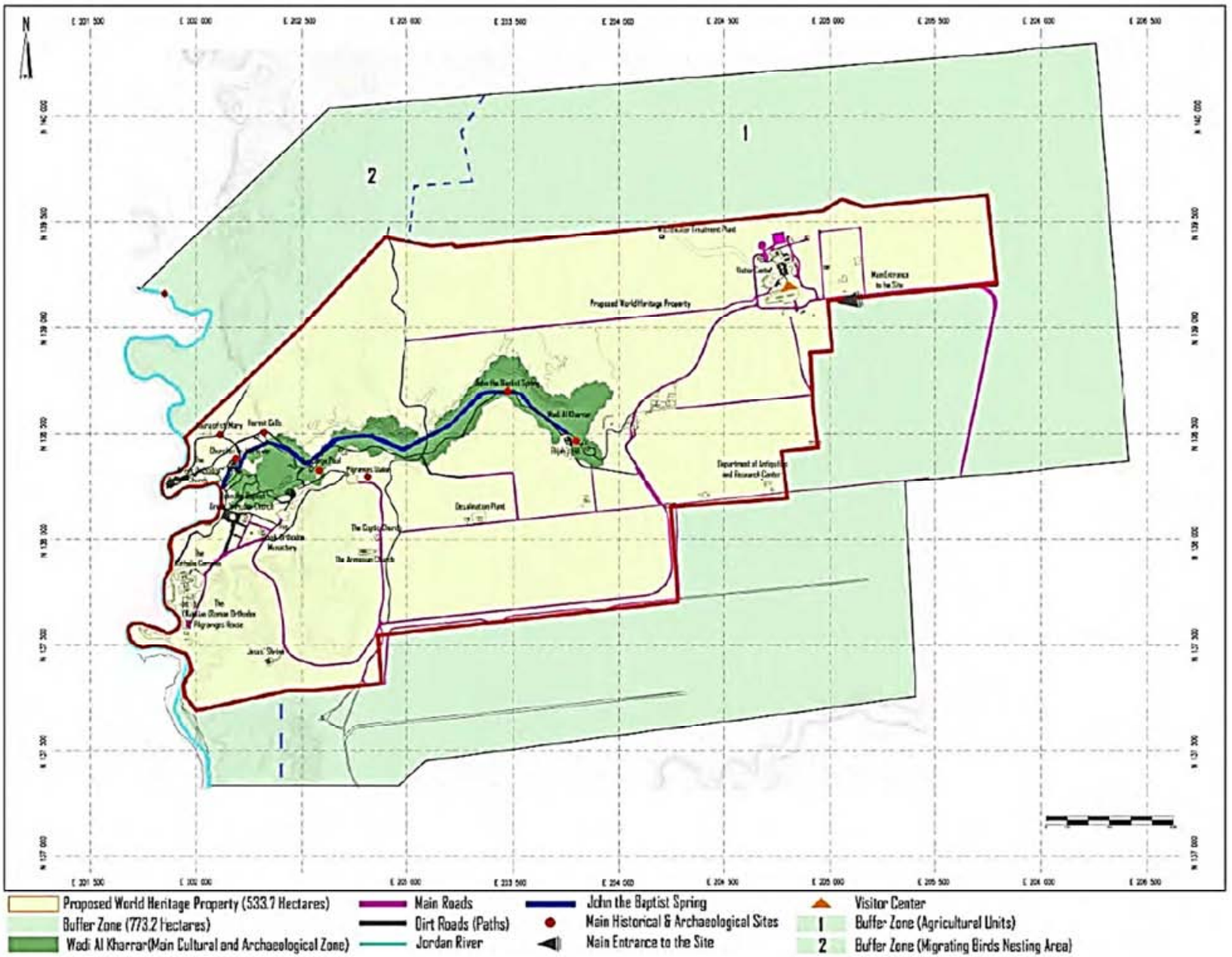

Figure 3. Map of the core of Bethany Beyond the Jordan and the surrounding zone.

According to some religious narration, when the believers crossed to the Bank on the other side of the Jordan River they established an altar in the location which is now known as (Qasr al-Yahud). In the reign of Emperor Anastazius (491$518 \mathrm{AD}$ ), an alter known as the alter of John the Baptist was built in this area and since its building in the year 500 AD the location was known as Bethabara Figure 3. [9]

The mosaic map in Madaba dated in the year 550 AD names this place as Bethabara, while the location in Al Kharrar Valley is named in the map as Ain Noon, i.e the place of the fountainhead which is now known as Saphsapha in attribution to the willow trees that are widespread in the valley. In this location that is shown in the Mosaic map, one could notice a cave which is larger than half a circle and above it there is half a dome which may symbol a fountain. [10] see Figure 4.

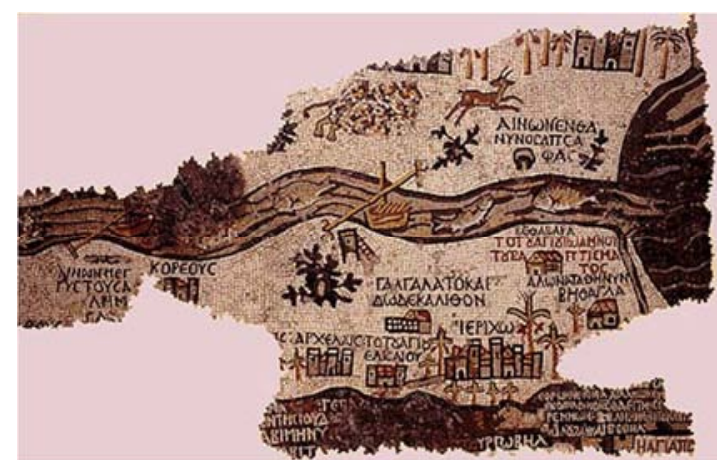

Figure 4. Madaba mosaic map with the River Jordan and Ainon of Bethany Beyond the Jordan. 


\section{Pilgrims \& Travelers Description}

Before mentioning what pilgrims and travelers said on the Jordan River and the sites located on its two banks, one should point to the fact that Al Kharrar Valley is linked to prophet Elijah who denounced paganism and deserted his people with his friend Elisha, crossing the Jordan River that was spliced apart by a small hill named as (Hermon) which is now known as the hill of Mar Ilyas. (Figure 5) From this hill Elijah was carried to the heavens by a storm (Kings 2: 6-11).

It is not a coincidence that people who came to John the Baptist- who lived across Jordan near the small hill- ask him if he was Elijah who returned back to earth and John denied (John 1:21) since he as Prophet Elijah used to wear rough clothes and lead an ascetic life. [11]

As mentioned above, Al Kharrar Valley is linked in the Christian religious concept the passage as well as Prophet Elijah and John the Baptist who used to preach baptism to forgive the sins. But what about Jesus Christ's baptism?

There must be a thorough review of the writings of travelers who visited the holy lands since the fourth century i.e. since Christianity was recognized as the official religion of the Byzantine period.

Pilgrims \&Travelers

The first traveler would be that who arrived from Borudex in France as a pilgrim in Palestine in the year 330 AD. This tells us that the place where John the Baptist baptized Jesus Christ lies five miles from the mouth of Jordan River in the Dead Sea.He said that above the river in that Bank a hill from which Elijah was lifted to the Heavens. [12]

It seems that Jerome (400 AD) pointed to the same location and linked it to the place where Jews crossed the river as well as the area where Elijah and Elisha reached when they crossed the river. He made it clear the link although indirectly between the passage area and the hill of Saint Elijah as well as the Baptism site.

Theodosius who visited Palestine in the year 530 AD gave a more detailed explanation and so he would be cited elaborately. Theodosius said that in the place where Jesus Christ was baptized there was a marble column with a metal cross fixed on it, adding that there was a church of John the
Baptist that was constructed by Emperor Anastasius. The church was very high since it was built on big vaults in case of water flow when floods take place Monks live in the church and earn six gold dinars that help them fulfill their daily life.There is a small hill known as Hermon in the place where Jesus Christ was baptized and from there Saint Elijah was ascended to the heavens. Saint Elijah blessed the fountain and above his grave the church was built. The distance between the place where Jesus Christ was baptized and the mouth of Jordan River in the Dead Sea is five miles. Regardless the contradiction in the ascending of Saint Elijah to the heavens and the existence of his grave near the small hill Hermon, Theodosius clearly shows that this hill lies across Jordan, where Jesus Christ was baptized. It is astonishing that this text is a description of the church built by emperor Anastasius "built on vaults in case of water flow when floods take place "This church is known as the church of John the Baptist, less than one kilometer from the river and therefore there is no need to build it over big rooms. It is clearly evident that this church mentioned by Theodosius is that one discovered near the river's east Bank. [13]

The following will tackle this church after mentioning what the well-known traveler "Antony the Martyr" who visited the site between the years 560-570 AD said.

"We approached this place, where Jesus Christ was baptized and the passage of the believers and from the same place Elijah was ascended to the heavens. On that bank of the river, there is the fountain near which John the Baptist used to baptize (it might be the fountain shown on Madaba's mosaic map, especially that its date coincides with that of the visit of Antony the Martyr).The destination from there to the river is estimated at less than two kilometers, and on its two banks lives the monks. We celebrate epiphany near the river, where one could see miracles that night where Jesus Christ was baptized. There is a hill surrounded with protection walland at the point where the water flows back to the valley there is a wooden cross fixed in the water and at the river's banks there are marble steps which take people to the water. Above the river, not far from where Jesus Christ baptized, John the Baptist's monastery. It is a big building and is comprised of two storey's.

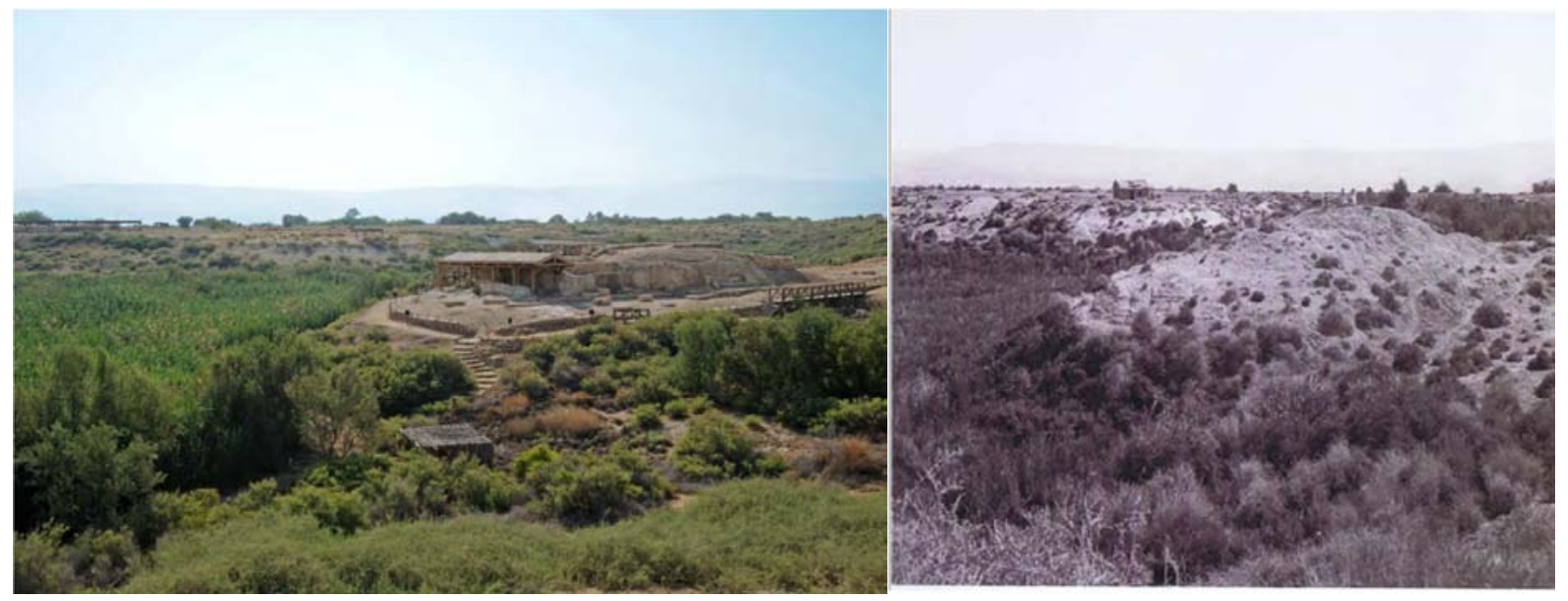

Figure 5. Photo of Elijah's Hill A-before excavations/ B-after excavations. 
At this point, it is worth discussion what Theodosius and Antony Martyr described. The first points to a marble column with a metal cross fixed above it. This column was located where Jesus Christ was baptized. It is hard to imagine such a column in a river, especially that baptism rituals took place from the 4th to the 6th of January, i.e. in the middle of the cold winter when the water of the river covers wide spaces on its two sides. It is possible that the cross fastened on top of stone foundation andwas located in shallow water near the mouth of Al Kharrar valley very close to Jordan River. It is worth notice that near this point the excavators discovered a square stone foundation built at the mouth of Wadi $\mathrm{Al}$ Kharrar designed to carry the marble column, and above a mid-height land, a huge church was discovered with colorful mosaic floors. Antony the Martyr, however, mentions the fountain, where John the Baptist used to baptize people. He says that near the place where Jesus Christ used to baptize, there is a hill surrounded with protectionwall, (here Antony refers to Tell Al Kharrar/Elijahs Hill)Antonycontinued,and at the point where water flows back to the valley there was a wooden cross in the water. Similarly, it is possible to imagine a wooden cross in the same river fastened on the same stone foundation after the collapse of the marble column by the flood of the River. Antony described the discovered Byzantine church near the River saying, Its hall was divided with very thick pillars when compared to other churches. It becomes clear that this church was destroyed because of earthquakes and was reconstructed more than one time. It could be the same church that Theodosius mentioned that was built by Emperor Anstazius. [14]Figure6.

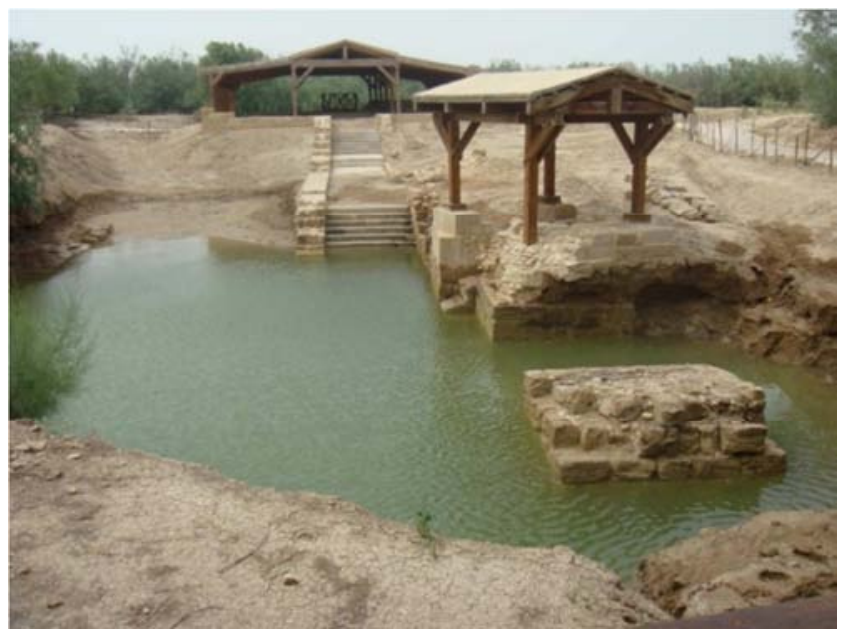

Figure 6. The small church, the steps and the monastery on the eastern bank of Jordan River (Waheeb: 2012).

Traveler Arculf, who visited the region in the year $670 \mathrm{AD}$ supports the idea that a church existed near the eastern bank of the river. Before quoting Arculf, one should point out that there is more than one script for Arculf's trip to the holy lands and some of them are not sound. Arculf said "that the wooden cross is located in the place where Jesus Christ was baptized on the other side another script said it was located at this side of the river. On the river, there is a small church, where Jesus Christ clothes were kept in the same place where he was baptized. This church is built over the water and eventually no one can stay in it because water flows under it and it is supported by four arches and vaults". He also points to a stone bridge that extended from the place where the wooden cross is located on the edge of the river. Pilgrims had to use this bridge and walk down to a valley to reach the river's bank where the wooden cross was located. This church could be the same one which Theodosius mentioned and was discovered near the river's east bank, but why did Arculf describe it as a small church? Historic sources speak about a big earthquake that hit the Jordan valley in the year 660- 759 AD. The tremor destroyed several churches and monasteries, including the church of John the Baptist that was totally destructed. It seems that the river located on the other edge of the river was also destroyed because of the earthquake and was reconstructed but in a smaller size. Arculf saw this church. Archeological excavations revealed valuable information about this church. A small church was discovered. The newly discovered church is a rectangular chapel given its small size, and measures $4 \mathrm{~m} \times 6 \mathrm{~m}$ and much of its south side has disappeared, probably due to erosion by the flooding of the Jordan River. The Jordan River today is about $150 \mathrm{~m}$ west of the chapel, and makes a large U-shaped loop around the area and also around the three other Byzantine churches there [15].As mentioned earlier, Arculf's description of the site is not clear. In one of his visits, he speaks about the baptism site and defines its location. On this edge of the river "the western edge" and then he adds that a strong man can throw a stone from this point to the other side of the river. But in this case, why the bridge? And why the walking above the wooden cross? Unless it is located on the eastern edge of the river. Almost 80 years after Arculf, i.e. in the year 754 Saint Philipa visited the baptism site. His description of the site did not differ from Arculf's but he added, however, that at this place, where baptism takes place there is a wooden cross in the middle. He also said that there is a small canal for water and a rope extended over the river and fixed on its edge. It becomes clear that the stone bridge at this time was destroyed and was replaced by the rope above the river. As mentioned above, it becomes clear the since the year $670 \mathrm{AD}$, if Arculf's information was adequate, baptism took place in the area close to the mouth ofAl Kharrar valley, i.e. on the eastern part of the river, By time, after destruction of the churches on the eastern part of the river, the baptism site was moved to the Hajlah crossing, one kilometer to the south of the other side. This place was favored by the Russian, Greek and Orthodox pilgrims. Year after year most of the architectural remains were forgotten and disappeared behind the thick trees and vegetation on the eastern side of Jordan River, the Orthodox and Latin again preferredthe eastern side of the River due to traditionsand gatheringnear John the Baptist's churchnear the mouth ofAl Kharrar. [16] Figure 7.

One can notice that the site where Jesus Christ was 
baptized not changed across centuries, the site where John the Baptist lived in preaching for the coming of Jesus Christ and the necessity of being ready for this occasion by salvation remained the same, in Bethany Beyond the Jordan.

\section{Site Development}

As an important religious site, several Christian Churches desire to have their presence in places of veneration and accordingly locations just outside the property have been and continue to be allocated for the construction of churches. Although these recent structures could be seen as compromising the authenticity of the setting of the site, they do not presently impinge on or negatively impact the central area containing the archaeological remains. [17]

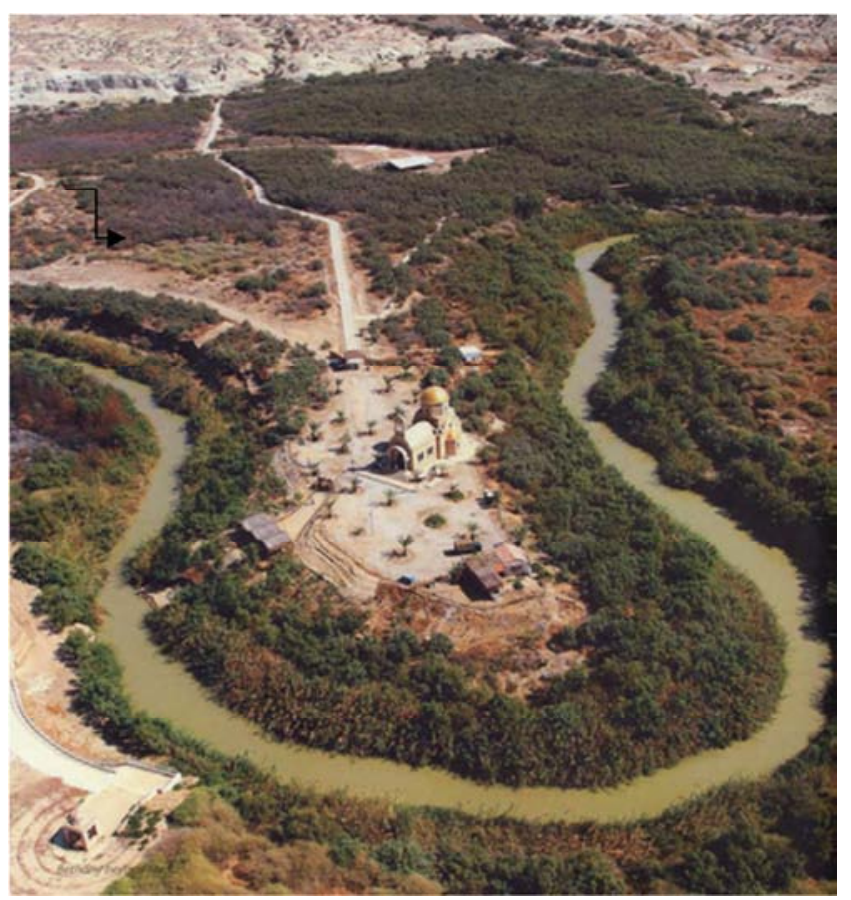

Figure 7. The recovered monastery on the eastern bank of Jordan River.

The archaeological areas have been preserved in their original materials, but have in many places been restored adding similar materials from the area to allow for easier interpretation or use of the structures. In some cases archaeological fragments have been reassembled and at times restoration work undertaken could be seen as reducing theauthenticity in material and workmanship. However, this reduction of material authenticity does not affect the significance or credibility attributed to the site by Christian believers

Some modern infrastructures have been provided to serve the needs of the visitors. These are mostly concentrated around the visitor centre, situated away from the archaeological area, to which one can access only via minibuses. The site is under the management of the Baptism Site Commission, a Site Management Plan was prepared which provided the required elements for the sustainable conservation, protection, maintenance, interpretation, and presentation of the site. [18]In the course of the preparation of the plan, a conservation assessment has identified the factors, natural and man-made, that affects or may impact the site if not properly managed. The management plan is a comprehensive analytical tool of the present state of conservation and might require some further streamlining to guide management strategies and activities in the future. The foreseen regular revision in an interval of five years will assist in this context. The current management arrangements already in place are largely adequate. Visitor access is controlled at one single entrance gate, which allows not only for the control of visitor numbers but also for the distribution of information and specific paths are laid out on site for the visitor walks and pilgrim processions to protect the remaining character of wilderness. [19] Figure 8. A series of policies and strategic actions have been identified to minimize impact while allowing visitors and pilgrims to enjoy the site in its authentic and untouched setting. The construction of several structures to perform religious services and allow pilgrims to stay in the vicinity of the site have been allowed, once the absence of archaeological remains or of negative impacts such as visual pollution have been proven. These structures will also relieve the pressure on the site itself, especially at times of increased visitation, such as at the time of Epiphany or at Easter. After excavations and consolidation of the archaeological remains conducted without introducing modern materials, the site was opened to the public, allowing also pilgrimages and ceremonies to take place there. Many Christian denominations have recognized officially the site as being the true location of the Baptism of Jesus, and the visit of two popes (John Paul II in 2000 and Benedict XVI in 2009, to which one must add also the programmed visit of pope Francis II in 2014) provides an indication of the importance that the Catholic Church attaches to the site.

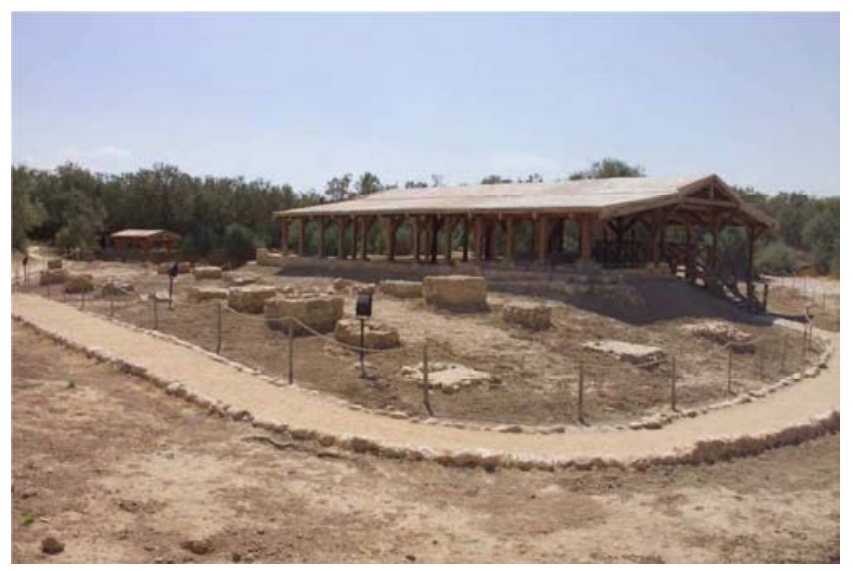

Figure 8. Site development included foot trails, shelters, signage system...etc.

Recognition of the heritage site points to the Jordan's astuteness in advancing the issue. There is huge tourism potential in the millions of Christians who could be interested in being baptized in the Jordan River at the same place as Jesus. Currently more than 100,000 pilgrims visit the site but 
the UNESCO recognition could increase that dramatically.

Inclusion on UNESCO's World Heritage list can bring economic benefits to Jordan, because as well as being a powerful tourist draw, world heritage sites are eligible for financial assistance towards preservation.

\section{Conclusion}

The recovered architecture remainsand artifacts were dating between the 1st and the 6th century CE from the Early Roman Period till the late Byzantine Period, and continued to the Islamic era. At present, the site has regained a popular status as pilgrimage destination for Christians, who continue to engage in baptism rituals on site.

Physical remains associated with the commemoration of the historic baptism event include a water collection system and pools as well as later built churches, chapels, a monastery, hermit caves, a cruciform baptismal pool, and a pilgrim station. These archaeological structures testify to the early beginnings of this attributed importance which initiated the construction of churches and chapels, habitation of hermit caves and pilgrimage activities. Beyond its key significance, the site is also associated with the life and ascension of Elijah (also called Elias) and Elisha, which is of common relevance to the monotheistic religions

"Bethany beyond the Jordan" is of immense religious significance to the majority of denominations of Christian faith, who have accepted this site as the location where Jesus of Nazareth was baptized by John the Baptist. This reference encouraged generations of monks, hermits, pilgrims and priests to reside in and visit the site, and to leave behind testimonies of their devotion and religious activities, dating to between the 4 th and the 15 th century CE. At present, the site has regained a popular status as pilgrimage destination for Christians, who continue to engage in baptism rituals on site. In 2002, faithful Christians commemorated the baptism of Christ there for the first time since the site's discovery in 1997, after the area was demilitarized following the 1994 peace treaty with Israel.

Since then, thousands of Christian pilgrims from around the world annually mark Theophany and Epiphany at the site. Epiphany (known to Greek Orthodox as Theophany) marks the revelation of Jesus Christ through his baptism and the beginning of his public ministry, according to Christian beliefs.

Finally it's clear that the kingdom's Hashemite rulers "who are the direct descendants of the Muslim Prophet Muhammad ... are the same ones who are protecting one of the holiest sites of Christianity in the Middle East.

\section{References}

[1] Waheeb, M. (1997). Report on the Excavations at Wadi alKafrein Southern Ghor (Al Aghwar). ADAJ, 41, 463-468.
[2] Abel R. (1932). Exploration du sud-est de la Vallee du Jordain, RB, 43 (Suie et fin), 237-263.

[3] Hershfield,Y. (1992) The judean Desert Monasteries in the Byzantinc Period. New Haven/London.

[4] Waheeb, M. (1997). Report on the Excavations at Wadi alKafrein Southern Ghor (Al Aghwar). ADAJ, 41, 463-468.

[5] Ibrahim, M. James, A.S. Khair, Y. (1996), The East Jordan Valley Survey, 1975, Bulletin of the American SchoolofOriental Research 222, 4 1-66 \& Salibi, Kamal. (1985), The Bible Came from Arabia, London, Jonathan Cape.

[6] Waheeb, M. (2011). The Hermit Caves in Bethany Beyond the Jordan,ANES,48, 177.

[7] Kopp, C. (1963). The Holy Places Of the Gospels, Germany.

[8] Eusibus,W, (1904). DasOnomasticon der biblischenortsnamen,leipzg.

[9] Hoade, E. (1954). "Western Pilgrims, Publications of the Stadium Biblcum Franciscanum, Jerusalem.

[10] Allita, E., \& Piccirillo, M. (1999). Madaba Map Centenary 1897-1997. Jerusalem

[11] Waheeb, M. (2012). The Discovery of Elijah's Hill and John's Site of the Baptism, East of the Jordan River from the Description of Pilgrims and Travelers, Asian Social Science Vol. 8, No. 8 .

[12] Wilkinson, J. (1977). Jerusalem Pilgrims Before the Crusaders. Aris and Philips Publishers, England. www.ccsenet.org/ass Asian Social Science Vol. 8, No. 8; July 2012212 ISSN 1911-2017 E-ISSN 1911-2025.

[13] Bernard P 1893, Theodosius on the Topography of the Holy Land 530 AD, Translated by J. H. Bernard, pp. PPTS, 1-19, Hanover,Square, London.

[14] Antoninus Martyr, 1896, Holy Places Visited by Antoninus Martyr, 560-570 A.D. PPTS, Translated by Aubrey Stewart, pp. 1-37, 24, Hanover Square, London.

[15] Waheeb, M. Abdelaziz Mahmod, Eyad Al-Masri (2013). A Unique Byzantine ComplexNear The Jordan InSouthern Levant And A Tentative Interpretation, Mediterranean Archaeology and Archaeometry, Vol. 13, No 2, pp. 127-134.

[16] Arculfs, A. (1895), The Pilgrimage of Arculfus in the Holy Land $670 \mathrm{AD}$, in PPTS, vol. 3, Translated and Annotated by James Macpherson, pp. 1- 64, 24, Hanover Square, London, AMS Press, New York.

[17] Naif Haddad; Mohammad Waheeb; Leen Fakhoury (2009). Tourism and Hospitality Planning \& Development, The BaptismArchaeological Site of Bethany Beyond Jordan: Towards anAssessment for a Management Plan, 6: 3, 173-190.

[18] Disi, A., Katbeh, A., Damhoreya, S., Wardam, B., Amr, Z.S., Khoury, F., Khader, I. and Budieri, A. (2001) Jesus Christ Baptism Site Management Plan (Amman: Ministry of Tourism and Antiquities of Jordan).

[19] Doan, P.L. (2006) Tourism planning and regional instability: the consequences of rapid expansion of the tourism sector in Jordan, International Development Planning Review, 28(3), pp. 311-332. 